\title{
Requirement and Architecture of Organization Development
}

\author{
Alireza Miremadi, Mir Mohammad Ali Golchobian, and Omidreza Ghanadiof
}

\section{ABSTRACT}

Traditionally, Iran was looking for development and either in era of oil revenues or before that, it has always faced serious mismatches in realization of plans. The results of studying activities in developmental organizations show that most of the activities in IRANIAN organizations are providing non-financial sources, assisting the technology development, and developing concentrated investment. In this research, we will review organization development types and factors that impact this, especially in IRANIAN organizations. Also, in this study, we evaluate the relation between civil development companies and export development companies. companies and export development companies.

Keywords: Organization Development, Privatization, Strategy.

\author{
Submitted : June 14, 2021 \\ Published : July 06, 2021 \\ ISSN: $2507-1076$ \\ DOI: $10.24018 / \mathrm{ejbmr} .2021 .6 .4 .932$ \\ Dr. Alireza Miremadi \\ Dean \& Assistant Marketing Professor, \\ Graduate School of Management, Sharif \\ University of Technology, International \\ Campus, Iran. \\ (e-mail: alireza.miremadi@gmail.com) \\ Mir Mohammad Ali Golchobian \\ Graduated of MBA, School of \\ Management, Sharif University of \\ Technology, International Campus, Iran. \\ (e-mail: golchoobian_mail@yahoo.com) \\ Omidreza Ghanadiof \\ Graduated of Industrial Management, \\ School of Technology, University of \\ Central Missouri, USA. \\ (e-mail: Omidof90@ gmail.com)
}

\section{HistORICAL SCENARIOS OF DEVELOPMENT}

Traditionally, Iran was looking for development and either in era of oil revenues or before that, it has always faced serious mismatches in realization of plans and indiscipline of definition, allocation of development budgets, and sometimes national and foreign borrowing: and in spite of defining development plans from 1971s, today, rare plans have been achieved in an acceptable and defendable manner, Meanwhile, Iran's Islamic Revolution adopted some fact changes in defining concepts like entrepreneurs, wealth, and the government's share. Also, structural evolutions in the type of ownership in industrial and contractors made historical evolutions in the process of development-centered organizations, due to the Islamic revolution. Sacred Defense period and afterward managerial and military, however, led to emergence of developmental organizations with totally new definitions and structure; and an actual potential for meeting developmental plans was provided, lack of policy, definition of mission, stakeholders, mutual relations and directing effective talents in the form of civil and development organizations as far as upgrading favorable development in the country, somehow led to unbalance between developmental plans and operational realization of plans. Although, many civil and development organizations were established in peacetime due to privatization process, redefining depot, logistic, and managerial missions by military forces as well as effective ideas of governmental agents outside of government during past two decades, including Khatam al-Anbia, Mapna, Kerman Development and Civil, Caisson, etc. these foundations are not rooted from defined, pre-architectural, and pro-operational talents, necessary for the country's developmental plans, but the tact of high-level agents and trustees in those organizations; and many disputable figures of more serious mismatches are recognizable in this way, so that governmental orientation for development and their goodwill approach - in absence of structured and professional agencies - has been realized in cooperation with inexperienced but good-willed claimers lead to expensive buzz cases like Afrashteh brothers, Amir Mansour Aria, Babak Zanjani [1]. While, after 8 years of notification of 1404 Perspective Document and un-realization of its core issues especially targeted growth rate (independent of various reasons), aforesaid mismatches have been increased in the process of developmental plan of the country and studying development patterns in developed and newlydeveloped countries at the region and intraregional level reveals the importance of "studying requirements and agriculture of civil organizations in Iran' as well as fostering development-support agencies in the country[5]. While the country is now faced with a multitude of developmentcentered vocabulary (twenty-years perspective, IranianIslamic model of development, lifestyle, sustainable development, land use planning, the ideals of the revolution, constitution, industrial development strategy, the fifth 
program regulation, privatization, Article 44 of constitution) and almost no regulated defendable operational plan is available for realization of goals; although on some especial events like presidential elections, a huge number of effective ideas would be provided but essential positioning as well as actual chasing of them among other issues, are always ignored. While, wide but less-developed regions in Iran geography still exists and Khuzestan land, desert, Makran and hundred villages are only a small part, and all these originate from "planning approach" and "lack of effective structures." It's worthwhile to concentrate on wise studies and practices in order to avoid any further mistakes and peaceful life with structural weaknesses and relying on opinions of professional elites (industrial and economical experts, experienced officials, approach of developed countries and review of executive experiences) and "studying requirements and architecture of civil development organizations in Iran" would be executed for a while in order to reconstruction and modernization of necessary institutions according to findings and an effective roadmap. May, a new way for development happens in the country.

A. Rapid pathology of civil development process in Iran and studying upstream regulations in civil development.

B. Codification of mission and strategies in civil development organizations.

C. Study of civil Development Landscape in Iran from the perspective of laws, social obligations (population, culture, regional and global competitiveness ...).

D. Identification, localization, and localization of organizational technologies in Civil development.

E. Rapid study of civil development pillars of competitive advantage in Iran (access rate, resources, competition...).

$F$. Organization architecture and map of main processes in civil development (building ideas, engineering, contracting, procurement, finance, quality management, legislative affairs, project management, insurance, marketing, sales, maintenance, development, stock, executive management, monitoring and control of organizational, social, national, bio stakeholders' rights).

$G$. Rapid study of common cooperation patterns in national, regional, and global civil development organizations.

H. Rapid identification of effective capacity of the Iranian Civil Development organization (GHORB, Mapna, Sazeh...).

I. Needs assessment in the field of leadership for civil development organizations (intellectual, behavioral).

$J$. Study of the effective parameters in exporting services of civil Developmental Organization (branding, strengthening foreign policy, documentation ...).

$K$. Identification of strategies to enhance the credibility of Iran in the field of Civil Development.

\section{ORgANIZATION DEVELOPMENT DEFINITION}

OD is a system wide application of behavioral science knowledge to the planned development and reinforcement of organizational strategies, structures, and processes for improving an organization's effectiveness [28]. In the other words, OD is a planned process of change in an organization's culture through the utilization of behavioral science technologies, research and theory from the above definitions following points emerge:

A. OD is a field of applied behavior science technologies.

$B$. It is related to plan change.

$C$. The study of $\mathrm{OD}$ is concerned with the total organizational systems and processes.

$D$. OD is related to achieving congruence among organizational components like structure, Culture and Processes.

E. OD is a long-term strategy intended to change beliefs, attitudes, values, and organizational Structures. It is carried out to achieve organizational effectiveness and meet the challenges of changed environmental factors.

$F$. The study of OD is aimed at developing overall organization with particular reference to development of organizations renewing capacity.

$G$. It involves initiating actions so that organizations are transformed into Learning Organizations.

To put in the nutshell, "Organizational Development is a long-term behavioral philosophy initiated by the top Management. It relates to use of latest technologies and organizational processes to affect planned change by establishing cultural framework based on vision, empowerment and Employee well-being leading to attainment of quality of work life and organizational effectiveness thus creating a learned organization."

\section{A. Types of Developmental Companies}

- Construction and Development Companies (Specialized): Focuses on the architecture and management of construction projects (roads, urban dev., dams, airports, oil, gas, petrochemical, food industry, metal industry, agriculture, aquaculture, animal husbandry, horticulture, etc.) through the use and management of contractor and consultant companies, design and construction and effective interaction with elements of commercial, industrial and government in each section.

- National Construction and Development Companies (Regional / Provincial): Focus on architecture and management of construction projects and regional development, including sectional and trans-sectional (tourism, trade, pilgrimage, residential, refining, industrial, rural, etc.) through implementation and management of specialized development and construction companies and effective interaction with commercial, industrial, and governmental elements of the areas.

- Transnational Construction and Development Companies (International): Focus on architecture and management of construction and development projects in other countries (tourism, trade, pilgrimage, residential, refinery, industrial, etc.) through the use and management of specialized development and construction companies, National development, and construction companies as well effective interaction with domestic and foreign elements of commercial, industrial, and governmental. 
- $\quad$ Export Development Companies (Goods \& Services): Focus on architecture and management of export projects in the fields of goods and services in other countries (marketing, product creation, market/product development, goods and services branding, setting up distribution and sales network, etc.) through the use and management of national and transnational manufacturing and service companies and effective interaction with domestic and foreign elements of commercial, industrial and governmental and transnational development and construction corporations.

\section{B. What is Sustainable Development?}

Sustainable Development in fact is making balance between development and the environment [18]. In 1980, the concept of Sustainable Development was first developed in IUCN. The organization uses this concept in the report of "environmental Maintenance Strategy" for describing a situation, in which development not only isn't harmful to the nature, but it also seems to be helpful. Stability has four aspects:

$A$. Sustainability of natural resources,

B. Political stability,

$C$. Social stability

D. Economic stability.

In fact, sustainable development not only focuses on environmental issues, but also on social and economic aspects. Sustainability development is the confluence of society, economy and environment.

One of the most important international events in the field of sustainable development is the World Summit on Sustainable Development (WSSD). In this session, participants were agreed on sustainable development [15].

The main agreements in WSSD are: decrease of people who hasn't access to water in half till 2015, minimizing chemical materials on the health of human and nature till 2020, decreasing the speed of sea sources to a sustainable level in half till 2015, slowing down the process of destroying natural variation till 2010, an increase of sustainability in usage of renewable energies and planning for compile a 10 years plan about sustainable development.

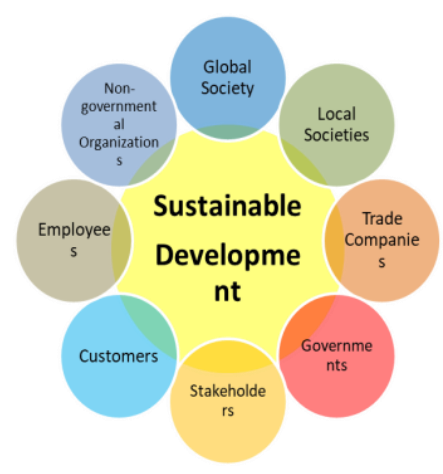

Fig. 1. Sustainable development.

However, today's, many politicians and environmental activists are seeking sustainable development; environmental campaigners believe that this option is not sufficient to protect the environment [7] and [10]. They believe that due to the trend of exploiting enable resources and destroying world's sources, the concept of "sustainable development" isn't true and other concepts like "Development Sustainability" must be used, because we do not actually believe in producing new resources.

\section{Research Objectives}

The following research question will be analyzed during this study. The research objective includes:

A. To discover the types of current organization development in Iran?

$B$. The analyze the expected services and results of development companies at expert, national and Transactional or export levels?

C. To discover the facilitation and stabilization of development privatization in Iran.

$D$. To determine the importance role of government board of directors and consultant in establishment of civil development.

E. To understand the various capability of organization development at expert, national and Transactional or export levels?

$F$. To highlight the importance of each organization development mission in stabilization of development in Iran.

\section{Comparison of Developmental Agencies in Iran and the World}

In the chain of economic and industrial development, the role of development agencies is the replacement ring for missing rings. In other words, these organizations facilitate the communications and operations in the industry and economy [9]. Facilitating industrial activities in the country through technology development, network development, Communication to businesses, management and human resource development, export development, promotion of investment and attracting foreign direct investment all are carried out by development agencies. In Iran, the Industrial Development and Renovation Organization is one of the oldest organizations in the country, however, after the implementation of the Article 44 of Constitution, it faced many policy challenges. According to the report of the deputy of fundamental Researches and production affairs of Parliament research Centre on applications of developmental organizations in Iran and the world, these are institutions that - due to the specifications of industry and economy, their needs and also strategic orientation of economy and the country's industry as well as in absence of similar organizations and private industrial and economical actors try to design services in general, and act through the development of economy in particular, and also the industrial development. Developmental organizations are effective tools of government to create new necessary activities for the country and also providing the context and capacities for empowerment of economic institutions that because of lack of financial resources, high risk, long-efficiency, etc. private sector can't or don't want to engage in. If the three pillars of the economy are defined as government, industry (supply side) and market (demand side), in developmental agencies would be the linkage among these three in order to facilitate the communication and operation. Even the most advanced countries in spite of high-developed economic characteristics and needs, are developing their own developmental 
institutions. "Economic Development Corporation of America", "Center for Industrial Development in China", "Investment Promotion Agencies and Industry Development in Italy", "Industrial Development in Malaysia" and "New Energy and Industrial Technology Development

Organization of Japan" are clear examples of this these development agencies. As evidence show, these organizations have played an important role in the industrial development of Asia, Latin America and other regions. Based on the research conducted, the services of industrial expansion and modernization that these agencies provide around the world can be classified into 6 categories:[9].

A. Development of Technology;

B. Clustering, Network Development and Business Communication;

C. Development of Management and Human Resources;

D. Development of Export;

E. Development of Investment;

F. Attracting Foreign Direct Investment.

TABLE I: ACTIVITIES SERVICES BY WORLD DEVELOPMENT ORGANIZATION

\begin{tabular}{|c|c|c|}
\hline \multicolumn{3}{|c|}{$\begin{array}{c}\text { Activities and services provided by the world developmental } \\
\text { organizations }\end{array}$} \\
\hline No & The kind of activity and services & $\begin{array}{l}\text { The amount of } \\
\text { concentration } \\
\text { (Percentage) }\end{array}$ \\
\hline 1 & Providing non-financial helps & $44 / 6$ \\
\hline 2 & Helping technological development & $13 / 8$ \\
\hline 3 & Helping investment development & $21 / 1$ \\
\hline 4 & Strengthening society's foundations & $6 / 7$ \\
\hline 5 & Providing financial helps & $6 / 3$ \\
\hline 6 & Marketing and market development & $4 / 6$ \\
\hline 7 & $\begin{array}{l}\text { Standards } \\
\text { competitiveness }\end{array}$ & $3 / 8$ \\
\hline 8 & Development of Human resources & $2 / 1$ \\
\hline 9 & Other & $6 / 3$ \\
\hline
\end{tabular}

Source: Industrial Renovation and development, the organization of Renovation and development of Iran's Industries. 2005.

The Focus of Activities in Developmental Agencies in America \& Canada: Activities focus on developmental agencies in America and Canada, mainly consist of deployment of information and communication systems, providing scientific, managerial, technical, academic, and professional training consulting services, facilitation, coordination and cooperation and the development of studies and research [4].

The Focus of Activities in Developmental Agencies in Africa: In African, development agencies are more active in the field of transferring knowledge, technology, and providing support for research and development of competition.

The Focus of Activities in Developmental Agencies in Asia: Asia is around the axis of studies extension, contributing to legislation, policymaking and planning, implementation of information systems and communication, providing scientific, technical and management consulting services.

\section{E. The Type of Ownership of Development Agencies in Studied Countries and the Role of Governments}

Studies show that most developmental organizations and agencies in America and Canada are privately owned, but most developmental organizations in Asian countries (Korea, Japan, and Malaysia) and also European countries are public, and parastatal run. Governmental development agencies offer similar services like private developmental agencies, and the only difference is in their ownership and source of financing. Private developmental agencies are largely influenced by the members. In governmental development organizations, government plays an important role, and these organizations could affect and facilitate governmental regulations, policies and trends like issuing production license, offering incentives for productive sectors, government's participation in joint industrial investments and incentives or tax exemption regarding industrial development. Studies show that over 84 percent of developmental organizations surveyed in Asia, are governmental and semi-governmental. This shows that even in Asian developed countries and developing countries, functions and goals of developmental agencies is administered according to public and semi-public ownership and management. Due to the experiences mentioned, venturing, stocks transactions, holding exhibitions, providing facilities for creating cooperatives, establishment of industrial parks and facilities for the modernization are of the activities that developmental agencies in the world have less inclination to do [10].

\section{F. Industrial Development and Renovation Organization of Iran}

Industrial Development and Renovation Organization of Iran is one of the most experienced institution of the country that over 46 years, plays an important role in the development of large-scale industries and motivating related industries [6]. These activities include industries such as automotive, marine and agricultural machinery, oil, gas and petrochemicals, and so on. After notification of Article 44 and providing the responsibility of poor regions to this organization (as the country's developmental organization), some challenges happened [14].

\section{G. Article 44 and Difficulties Ahead}

Based on the report of Iran's Parliament Research Center, especially after the enforcement of Article 44, this organization has difficulties in five-axis including timeconsuming process of approval for developmental projects, inadequate allocation of resources gained through assignment, difficulties of managing companies during transfer, problems arising from the companies' commitment after transfer, and assignment of some part of the company's commitment in the form of debt rejection. Given these challenges, the parliament's research center has suggested:

A. According to the economic literature and application of developmental organizations in the world, and also current responsibilities that have been considered for this organization, it's necessary to reform its statute due to the current conditions and Article 44 constitutional approaches and also fifth plan of development.

B. The transfer of resources from its subsidiaries directly to the organization for use in developmental projects. Prioritizing the transfer of companies and including only the companies that the probability of their sale is high

C. Regarding reduction or coverage risk of commitments and guaranties of subsidiaries, it is suggested that while contracting assignment, all debts and loans and guarantees of the company to transfer should be assigned to buyer. 


\section{H. Issuing the Licensing of Investment for Development Organizations according to Article 44}

President Mahmud Ahmadinejad ordered for the participating of developmental organizations to investment in the field of some policies and activities of Article 44 of the Constitution (new technologies and high-risk industries) up to 49\%. Citing Note (3) Paragraph (a) of Article 3 of the Law of amending materials of the Fourth Economic, Social and Cultural plan of development of Islamic Republic of Iran, and also the implementation of the general policies of Article 44 of the Constitution Approved at 2008, and the compliance with decree No. /151247 $ت 34505$ odated 20-07-2009, the ministry members of Supporting Production Workgroup agreed with the participation of developmental organizations in investment at activities of group one Article 2 of General Policies of Article 44, up to $49 \%$. Under this legislation, developmental organizations are allowed to participate with private sector up to 49 percent in the context of their statute and regulations for investment in the activities of substance (2) of mentioned law in new technologies and high-risk industries as attachments that have been confirmed by the government or in less developed areas and the title of the decree No. /76254 36095 odated 1.04.2008 in compliance with laws and regulations involved. This canon was approved this April by president and First Deputy of president also imparts it to ministries of industries, Mines and economic affairs and assets to implement.

\section{High Tech Industry Definition}

[10] exploit high technology and technical knowledge, innovation, and creativity play an important role in the definition and development of them. Main characteristic of these industries includes providing added value, dependence on expert acknowledged human resource, and affecting other service and product sectors through increase of efficiency; this aspect would be highlighted besides fostering competitive position in macro-levels. Also, these industries are based on the knowledge and main part of its technical know-how is brain-ware that would be realized by the integration of new technologies. In addition to professional technical knowledge besides the requirements and pre-requisites like equipment, production line and qualified materials, these industries are dependent on a strong information infrastructure.

\section{J. The Main Features of High-Tech Industries}

A. They are high-tech at least one of the three substrates (processes, machinery, and equipment).

$B$. Products and output of these industries are high-tech equipment and services.

C. Maximum use of automated production methods has contributed.

D. R\&D expenditure is high (at least twice the average in other industries).

E. Compared to technologies in other industries, the rate of change in high-tech industry is rapid.

$F$. Having the potential (capacity) and the power of using technology for rapid growth.

$G$. The ration of expert, educated, and professional human resources in the industry consists at least twenty percent of total employees.

High-technology industries are classified as follows:
A. The electronic industries (design and construction): computer and its related fields except assembly processes (DKS), integrated circuits, production of advanced electronics and communication equipment

$B$. The industries of producing new materials: advanced ceramics, composites, advanced polymers, superconducting materials

C. Biotechnological industries: all advanced pharmaceutical products and diagnostic kits, nutritional supplements, biopolymers, biological reactors, biotechnological chips, production of a variety of biological fertilizers and enzymes

D. Optics and Laser: all types of lenses, laser application equipment, optical fiber, crystals and optical thin films, IT \& Mechanic

E. Industrial automation and intelligent systems: processes control systems and equipment, instrumentation, heat control, sensors, robots

F. Nanotechnology: Nanotechnology applications in various fields such as electrical engineering, computer science, medicine, the environment, energy, etc.

$G$. Industries related to information technology (IT): design and production of software packages for data transfer and information networks services, information, and communication systems

$H$. Aerospace industries: aerial navigation systems, aerodynamics, and flight mechanics, building civilian aircraft, satellite technology

I. Renewable Energy: Fuel Cell and Solar Inverters.

Also, in the appendix of the canon of state is asserted that: in Iran, due to the novelty of these industries as well as their relative high risk, the private sector is not able to develop them independently and the realization of these technologies would not be possible without governmental management and providing necessary infrastructures. In light of the foregoing, advanced deployment and development will be explained by high quality, lower cost, and improved international competitive position. According to the appendix of this canon, so, as pioneers, generators, and motivators of high-tech industries, related governmental organizations would invest in these fields and provide the possibility of participation and presence of private sector. Obviously, in all societies, appropriate motivational policies as well as investment of state-owned organizations in different fields of high-tech industries that lead to establishment of successful and justifiable businesses, gradually encourages private sector investors to participate in related plans, enter technical knowledge and its application, and finally, achieving the superior competitive position internationally [24].

\section{K. Industrial Towns Transform to Developmental Organization/State Sovereignty is not transferable}

MPs agreed to rename the Organization of Small Industries and Industrial Towns to Developmental Organization. At the public forum on Sunday, October19, 2013, the Parliament representatives - during the review of the amendment of Clause 5 of Article 3 of the amending Law on the implementation of Article 44 of the constitution - agreed to rename the Organization of Small Industries and Industrial Towns of Iran and its provinces to Developmental Organization, according to which no governmental affair are 
transferable. With 175 votes in favor, 4 against and 8 abstentions of total 232 present representatives in the parliament, representatives agreed with Note 5 paragraph (a) of Article 3 of the amending Law of implementation of Article 44.[27] In the Clause of Note 5, paragraph (a) of Article 3 from the Law Enforcement of general policies of Article 44 read that this note is approved at 03.16.2009 and its further improvements are as follows: Clause 5 - the Organization of Small Industries and Industrial Towns of Iran and its related provincial subordinate is approved as Developmental Organization and its state-owned affairs are not transferable.

Assignment of industrial towns and regions to owners of their established units would be performed according to the Law of conditions of transferring the ownership and administration of Industrial towns affairs approved 22-2-2008 and the Ministry of Industry, Mine, and Trade is obliged to fully implement the law and transition of management to above-mentioned service companies till the end of fifth fiveyears plan of Islamic Republic of Iran.

About non-governmental real and legal identities demanding establishment of industrial towns or regions in private or governmental lands within or outside of cities privacy, the organization's subordinate units are obliged to issue the certificate for applicant, according to related regulations; they must support the applicants, in addition to providing supervision. [22] At the poor regions and lessdeveloped regions where industrial towns and regions are not transferred, or at the regions where there is non-governmental applicant for building industrial towns and regions, the Organization of Small Industries and Industrial Towns of Iran and its related provincial subordinate are responsible for establishment, providing services and infrastructures [19]. The statute and organizational hierarchy of Developmental Organization and its provisional subordinates as well as differentiation of governmental and non-governmental responsibilities, are determined in the bylaw of this Note that would be issued maximum three months after the date of its necessitation by the Ministry of Industry, Mine, and Trade in cooperation with the Presidential Deputy of development of management and human resource as well as the Ministry of economic Affairs and Finance and would be approved by the Council of Ministers[17]. Flowingly, Abbaspoor, Spokesman of Parliaments' industries and Mines proposed for interpolation of a Note to the Article of mentioned plan according to which, the Petroleum technology and Research Company is a developmental fundamental research unit that its activity is toward self-sufficiency as corporate governance. In this regard, objecting to inclusion of this Note to the mentioned plan, Mohammad Ghasim Osmani said: "Discussed law is about Industrial towns and based on proposed Note, the Technology and Research Company shouldn't transfer to private sector. This proposal has no relation to discussing Law." Agreeing the inclusion of a Note to the plan, Iraj Nadimi also said: "the research relationship of private sector has been yet acknowledged in the country."

The Member of Industries and Mines of Parliament added, it's a long time, we are saying about necessity of development of petroleum in the parliament. But is it possible to comment about world's new productions without research. At the end, representatives agreed the inclusion of a Note to mentioned bill with 118 votes in favor, 25 against and 14 abstentions votes out of total 222 present deputies in the parliament [25]. Flowingly, Hamid Reza Fouladgar asked for the incorporation of amendments to paragraph (a) of Article 3. He said, participation and investment of developmental organizations in the country is legally allowed for the activities included in Group 2 Article 2 of this Law and according to their statute and establishment law, providing the meeting of determined level for market share - the subject of Note 1 paragraph B Article 3 - provided that the conditions for participation and investment are within Group 2 and excess of the ceiling set for this group are to be transferred within three years of operation start. Fouladgar continued that stock, shares and organizations' priority in ventures of groups 1 and 2 will be administered by the organization till it not assigned to [21].

The representative of Isfahan province reminded, according to conditions of paragraph $\mathrm{D}$ of general policies of transfer in Article 44 and also Article 29 of Law of implementation of general policies of Article 44, fund by transfer will be settled in National Treasury and 70 percent of them would be allocated to aforesaid organizations to be spend for cooperation with non-governmental sectors and economic development of less-developed regions, completing semi-conducted plans, performing governmental responsibilities, high-tech, and preparing the ventures to transfer. According to the report, the Parliament representative agreed with the incorporation of the mentioned Note to the amendment of Clause 5, paragraph (A) Article 3 for Law of Implementation of Article 44 General Policies by 158 votes in favor, 15 against and 8 abstentions.

\section{Unaccomplished Old Youths," the Phenomenon of Iran's Future}

The professor at Tehran University, Social Sciences Faculty, said: "In our society, economic and cultural homogenization as well as developmental policies have studied all population through distant learning that you need the government, so, we really feel actual dependence and may hide our capacities."

According to Isna, at the Seminar of Examining the status of Social Forces in Iran- held in Jihad Social Sciences Research Centre - Dr. Taghi Azad Armaki said: "In Iran, we are faced with a huge number of social forces. Looking back the history, we will find a series of former zero elements like clergymen, which our social community emerges from.

He added, through social changes and transfer, we faced forces that were somehow the substitutions of the same former zero, such as technocrats, women, intellectuals, and so on. In fact, the Islamic Revolution is a combination of former forces like politicians, technocrats and as well as clergymen, women, and intellectuals [20].

Mentioning to the importance of living as the critical issue of Iran's contemporary world, Azad Armaki asserts: "The importance of living is an issue that emerges in all aspects of Iran's social forces and in fact, the concept of justice has transformed to the concept of living in the society." The professor of Tehran University said that in the past, people were justice-oriented and the benefit of the whole was focused, so, Islamic Revelation happened. But today's society is focused on the concept of living and one of the main values emerged from, is individualism. He pointed to the prospect of social forces in Iran and said: "Iran's today and tomorrow is 
affected by a phenomenon known as "immigrants" that should be taken into serious consideration. In fact, immigrants are affected by the individualism and individualistic conception of living because importance of individualism would definitely lead to immigration. According to [26] Azad Armaki, Iranian immigrants tend to high-profile countries, and they are even very productive there, but socially, they are classified as middle classes because their essential issue is change and improvement of lifestyle. He mentioned to another perspective of social forces in Iran as "unaccomplished old youths" and said: "At the near future, we will be faced by the issue of unaccomplished old youths whose main problem of living is not solved yet and we also will lose our youths' capabilities for making the society and enter to the aging stage of youth. Armaki mentioned to "poor possessors" and "wealthy poor" as another aspect of Iran's social forces and said: "we have two social types in the society that are: wealthy people who feel poverty. They are those who are not willing to voluntarily bestow their subsidies to the poor people; in fact, they try to hide their capacities. The professor of Tehran University said: "In our society, economic and cultural homogenization as well as developmental policies has studied all population through distant learning that you need the government. So, our policies limited the power of high and middle class families to find their actual position in the society and as far as our policies were focused on organizing poor people, the wealthy people also feel insolvency while they are actually in the low middle class." The professor of Tehran University believes that nowhere, this 30 times class difference happens and in fact, Iran has the most class hierarchical society in the world. Mentioning to poor possessors, he said that these have-nots are located in the middle class while they are lower middle class. Pointing to the research on social classes, he asserts: "In this research, 70 percent of participants were reported themselves as middle class. But it isn't true because a major part of them is classified as high and middle classes." Mentioning the prospect of tomorrow's social destiny in Iran, he said: "In a society whose main concern is living, and it is not willing to ignore its concern, the possibility of radical movement fades. In other words, given to current situation, the possibility of a radical movement never exists in the future of Iran.

\section{ReSEARCH Methodology}

Research in common parlance refers to a search for knowledge. One can also define research as a scientific and systematic search for pertinent information on a specific topic. In fact, research is the art of scientific investigation. The advance learner's dictionary of current English oxford lays down the meaning of research as "a careful investigation or inquiry especially through search for new facts in any branch of knowledge" [16], [11] has classified research divided into three basic types: Survey, historical and experimental methods. In this research, the survey method has been employed. It focuses on the present situation and attempts to find the object under investigation. This method is classified into four categories:(a) Descriptive (b) Analytical (c) School survey and (d) Genetic.
The research design utilized in this study was a descriptive survey design. [11] describe that a descriptive survey involves asking a large number of individuals the same set of questions. The main advantage of this type of research is to provide a lot of information from a large sample of individuals. Fraenkel and Wallen state a list of three major characteristics that most surveys possess:

A. Information is collected from a group of people in order to describe some aspects or characteristics of the population of which that group is a part of.

$B$. The main method in which the information is collected is through asking questions; the answers to these questions by the members of the group constitute the data of the study.

C. Information is collected from a sample rather than from every member of the population.

\section{A. Data Analysis and Interpretation}

The population of this study is to find out the current organization development in Iran. the current type of organization development is captured by Civil development companies and export development company that are captured $33.3 \%$ equally and second placed is National development Companies with $20 \%$ and the last one is Transactional Development Companies. (Table II)

\begin{tabular}{ccccc}
\multicolumn{5}{c}{ TABLE II. ORGANIZATION DEVELOPMENT TYPES } \\
\hline & Frequency & Percent & $\begin{array}{c}\text { Valid } \\
\text { Percent }\end{array}$ & $\begin{array}{c}\text { Cumulative } \\
\text { Percent }\end{array}$ \\
\hline $\begin{array}{c}\text { Civil Developmental } \\
\text { Companies (Expert) } \\
\text { National Civil }\end{array}$ & 5 & 33.3 & 33.3 & 33.3 \\
$\begin{array}{c}\text { Developmental Companies } \\
\text { (Regional/Provincial } \\
\text { Transnational Civil }\end{array}$ & 3 & 20.0 & 20.0 & 53.3 \\
$\begin{array}{c}\text { Developmental Companies } \\
\text { (Regional/National) }\end{array}$ & 2 & 13.3 & 13.3 & 66.7 \\
$\begin{array}{c}\text { Expert Development } \\
\text { Companies (Goods \& } \\
\text { Services) } \\
\text { Total }\end{array}$ & 5 & 33.3 & 33.3 & 100.0 \\
\hline
\end{tabular}

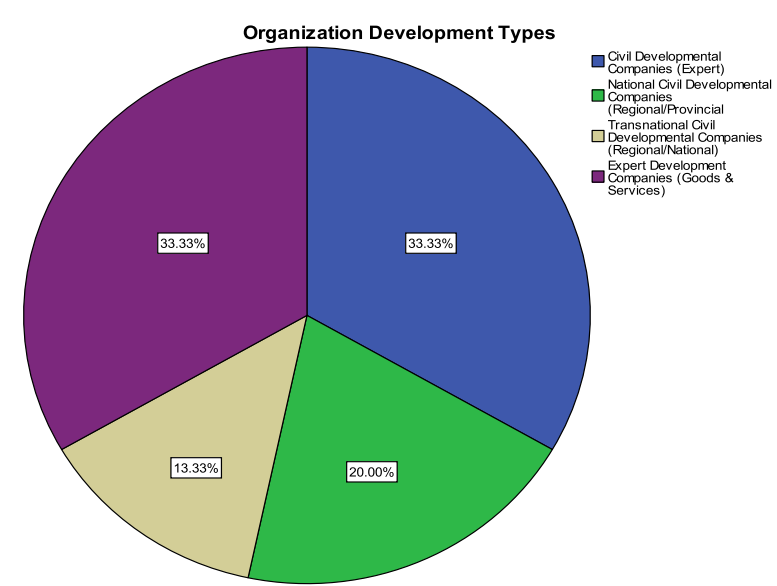

Fig. 2. Market Share of Variety Types of Organization Development.

\section{B. Reliability and Validity Tests}

As it is seen Validity and Reliability were described in detail in Chapter 3. Here we use Factor Analysis to know which factors or components of each variable is valid and should remain and which factor or component is not valid and should be eliminated. 


\section{Reliability Test}

According to [13], to obtain coefficient alpha the average of the coefficients should be calculated from all possible combinations of split halves. Coefficient alpha ranges from 0 to 1 . The interpretation for alpha values is in the following table as rules-of-thumb (Refer to Table III). Researchers generally consider an alpha of 0.7 as a minimum, although lower coefficients may be acceptable depending on the research objectives.

TABLE III RUles of Thumb ABout Cronbach-Alpha CoEFFicient Size

\begin{tabular}{cc}
\hline Alpha Coefficient Range & Strength of Association \\
\hline$<0.6$ & Poor \\
0.6 to $<0.7$ & Moderate \\
0.7 to $<0.8$ & Good \\
0.8 to $<0.9$ & Very Good \\
$\geq 0.9$ & Excellent \\
\hline
\end{tabular}

If alpha $>0.95$, items should be inspected to ensure they measure different aspects of the concept.

TABLE IV INTERNAL CONSISTENCY OF QUESTIONNAIRE

\begin{tabular}{ccc}
\multicolumn{3}{c}{ TABLE IV INTERNAL CONSISTENCY OF QUESTIONNAIRE } \\
\hline Variable & $\begin{array}{c}\text { Number of } \\
\text { Components }\end{array}$ & $\begin{array}{c}\text { Cronbach's } \\
\text { Alpha }\end{array}$ \\
\hline $\begin{array}{c}\text { Expect service and Result } \\
\text { Stabilization and } \\
\text { Facilitation }\end{array}$ & 7 & 0.753 \\
$\begin{array}{c}\text { Role of Board of directories } \\
\text { and Consultant in civil } \\
\text { Development }\end{array}$ & 5 & 0.69 \\
\hline
\end{tabular}

The value of cronbach's alpha for 3 constructs (main variables) of this study is indicated in TABLE IV. According to the rules of cronbach's alpha coefficient, since the value for all the constructs are higher than $0.7(0.7$ to $<0.9)$, the result of internal consistency reliability for constructs of this research is Good.

\section{Factor Analysis}

Validity Test is the ability of desired tools in measuring the attribute which the test has been made to measure. One of the ways to examine the validity of the study indicators is factor Analysis. In factor analysis, first it should be ensured that existing data can be used for analysis. In other words, is the amount of data appropriate for factor analysis or not? For this purpose, KMO (Kaiser-Meyer-Olkin Measure of Sampling Adequacy) measure and Bartlett's (Bartlett's Test of Sphericity) test is used. TABLE V: shows the results containing KMO measure, Batlett's test amount, degree of freedom and Sig. The initial factor analysis is run using the principle components analysis method in the SPSS window. The result is satisfactory since KMO MSA value for three main constructs is higher than 0.6 and none of the attributes shows the Extraction value below 0.5 which is taken as the minim level for acceptance. This article has been structured on the basis of confirmatory factor analysis. Nevertheless, for deducting the most important attributes and knowing if there is the permission to use the previous clustered models or not, we use the first step of exploratory factor analysis.

Furthermore, validity is the property by which a questionnaire measures what it is supposed to measure, for example, if the researcher wants to measure impact of organization development in Iran, therefore research take advantage of face and content validity as well to run the questionnaire among the expert segments.

\begin{tabular}{lcc} 
TABLE V: KMO AND BARTLETT'S OF ORGANIZATION DEVELOPMENT \\
\hline KMO and Bartlett's Test & & \\
\hline Kaiser-Meyer-Olkin Measure & & $\underline{.856}$ \\
of Sampling Adequacy. & & 1950.152 \\
Bartlett's Test of Sphericity & Approx. Chi-Square & 66 \\
& Df & .000 \\
\hline
\end{tabular}

\section{E. Friedman Test}

The Friedman test is the non- parametric alternative that can be used to test the differences between groups when the dependent variable being measured is ordinal. The Freidman test compared the mean rank related factors and indicated how the factors differed.

It is really interesting to know that organization development can achieve excellent result when the government seriously improves the directing the political forces to development and decrease the amount of financial corruption in Iran although the plus point of organization development is Executive forces and should be considered as hub point in current government (Table VI) [23].

\section{TABLE VI EXPECTED SERVICE AND RESULT OF ORGANIZATION}

\begin{tabular}{lc}
\multicolumn{1}{c}{ DEVELOPMENT IN IRAN } & \\
\hline Executive Force of Developmental Plans & $\mathbf{5 . 6 3}$ \\
Exacting technical, economic, social, political, & 4.77 \\
$\begin{array}{l}\text { and military pensioners } \\
\text { evelopment of services export and management }\end{array}$ & 4.57 \\
foreign markets & 4.33 \\
ttracting national and foreign investments & 3.3 \\
Rploiting Factor (exploitation, maintenance, & $\mathbf{2 . 7 3}$ \\
epairs, development) & $\mathbf{2 . 6 7}$ \\
\hline irecting Political Forces to development &
\end{tabular}

TABLE VII revealed that the essential factors that influenced in facilitation and Stabilization of development privatization could be summarized in TABLE VII. Researcher discovered that the vital factor that needs to improve seriously is social force that directs government to omit the possibility of hurting social. Environmental, cultural logistic and it is considered as external forces as first position and financial as internal force as send factor need to revise completely.

TABLE VII: FACILITATION \& STABILIZATION OF DEVELOPMENT (INTERNAL \& EXTERNAL)

\begin{tabular}{lc}
\multicolumn{1}{c}{ (INTERNAL \& EXTERNAL) } \\
\hline \multicolumn{1}{c}{ Ranks } \\
\hline \multicolumn{1}{c}{\begin{tabular}{c}
\multicolumn{1}{c}{ Mean } \\
Rank
\end{tabular}} \\
\hline $\begin{array}{l}\text { Trade: Ability of Trade Activities in Related Fields And } \\
\text { Guarantying Investments \& Attempts (Internal) }\end{array}$ & 3.37 \\
$\begin{array}{l}\text { Security: omitting the possibility of hurting political } \\
\text { economic, social, and military security (internal/external) }\end{array}$ & 3.2 \\
$\begin{array}{l}\text { Legal: meeting competitiveness regulations, removing } \\
\text { Cartel, trade regulations for real and legal identities } \\
\text { (external) }\end{array}$ & 3.1 \\
$\begin{array}{l}\text { Financial: monetary capacity for running venture, plan, or } \\
\text { project (monetary, credit capacity, attracting }\end{array}$ & 2.93 \\
$\begin{array}{l}\text { investments...) (internal) } \\
\text { Social: omitting the possibility of hurting social, } \\
\text { environmental, cultural logistic in the field of activity } \\
\text { (external) }\end{array}$ & 2.4 \\
\hline
\end{tabular}


The researcher also discovered that important role of shareholder, member of board of directories and consultant in establishment civil developmental companies the clergyman and retired commanders of Iranian revolutionary guard need to improve substantially. The result advised us to construct the essential policy for directing of quaternary civil developmental companies (TABLE VIII.).

TABLE VIII. DIRECTION OF CIVIL DEVELOPMENTAL COMPANIES

\begin{tabular}{lc}
\multicolumn{1}{c}{ Ranks } & $\begin{array}{c}\text { Mean } \\
\text { Rank }\end{array}$ \\
\hline $\begin{array}{l}\text { Investor or Entrepreneur: Establishment \& Trade } \\
\text { Management Consulting Companies (Directing and }\end{array}$ & 8.7 \\
$\begin{array}{l}\text { Supply of Management Tools \& Systems) } \\
\text { Bank (Directing and Supply of Cash Flow and Financial } \\
\text { Management) }\end{array}$ & 6.97 \\
$\begin{array}{l}\text { Professional Association, Provincial Chambers: Expert } \\
\text { Trade Directing as Well as Market Supply and Trade }\end{array}$ & 6.6 \\
$\begin{array}{l}\text { Negotiations } \\
\text { Custom High Official (Pensioner): Legal Direction, }\end{array}$ & \\
$\begin{array}{l}\text { Supply and Facilitation of Trade Relations at The } \\
\text { Framework of Legal Regulations }\end{array}$ & 5.4 \\
$\begin{array}{l}\text { The Deputies of Ministers and Governors (Former): } \\
\text { Executioner Direction, Supplying Bureau Knowledge, }\end{array}$ & 5.2 \\
$\begin{array}{l}\text { Facilitating Relations in Offices Based on Regulation } \\
\text { Parliament Members: Executioner Direction, }\end{array}$ & \\
$\begin{array}{l}\text { Facilitating Regional Relations, Legal Lobbying at The } \\
\text { Framework of Legal Regulations }\end{array}$ & 4.77 \\
$\begin{array}{l}\text { Retired Ambassadors: Directing Foreign Trade } \\
\text { Relations and Supplying Effective Trade Relations at } \\
\text { The Framework of Legal Regulations }\end{array}$ & 4.53 \\
$\begin{array}{l}\text { Retired Commanders of Iranian Revolutionary Guards, } \\
\text { Military or Police: Security Directing as Well as Supply } \\
\text { and Facilitation of Guard and Logistic Affairs. }\end{array}$ & 3.4 \\
$\begin{array}{l}\text { Clergymen: Directing Social Approaches as Well as } \\
\text { Supply and Facilitation of Social and Regional Supports }\end{array}$ & 2.57 \\
\hline
\end{tabular}

TABLE IX: stated that capabilities of developmental organization at professional, National and transactional level, or export level to reinforce organization development. Supply and Provision as first place and share management as second place are essential fields in this area to protect the organization development in current Iranian government.

TABLE IX: REINFORCE OF ORGANIZATIONAL DEVELOPMENT

\begin{tabular}{lc}
\hline \multicolumn{2}{c}{ Ranks } \\
\hline Mean Rank \\
\hline Creating Ideas & 10.7 \\
Marketing \& Sales & 10.23 \\
Risk Management & 9.73 \\
Development & 9.7 \\
Quality Management & 8.47 \\
Finance and Cost Management & 8.37 \\
Contracting & 8.23 \\
Shareholders' Management & 7.6 \\
Plan and Limitation & 7.43 \\
Management & 7.3 \\
Human Resource Management & 7.1 \\
Maintenance A\& Repair & 7 \\
Communication and & 6.97 \\
Entertainment & 6.17 \\
Share Management & 5 \\
Supply and Provisions & \\
\hline
\end{tabular}

TABLE X: ORGANIZATION DEVELOPMENT TYPES Ranks

\begin{tabular}{lc}
\multicolumn{1}{c}{ Ranks } & \\
\hline \multicolumn{1}{c}{ Mean Rank } \\
\hline $\begin{array}{l}\text { Civil Developmental Companies (Expert) } \\
\text { National Civil Developmental Companies } \\
\text { (Regional/Provincial) }\end{array}$ & 2.93 \\
$\begin{array}{l}\text { Expert Development Companies (Goods } \\
\text { and Services) }\end{array}$ & 2.5 \\
$\begin{array}{l}\text { Transnational Civil Developmental } \\
\text { Companies (Regional/National) }\end{array}$ & 2.4 \\
\hline
\end{tabular}

\section{DISCUSSION AND CONCLUSION}

Organization development offers a prescription for improving the "fit" between the individuals and the organization, between the organization and the environment, and among the organizational components such as strategy, structure and process. The prescription is implemented through inventions and activities that address specific problematic conditions. Organizational development is a continuous process. Meanwhile, Iran's Islamic Revolution adopted some fact changes in defining concepts like entrepreneurs, wealth, and the government's share. However, today's, many politicians and environmental activists are seeking sustainable development; environmental campaigners believe that this option is not sufficient to protect the environment. According to the report of the deputy of fundamental Researches and production affairs of Parliament research Centre on applications of developmental organizations in Iran and the world, these are institutions that due to the specifications of industry and economy, their needs and also strategic orientation of economy and the country's industry as well as in absence of similar organizations and private industrial and economical actors try to design services in general, and act through the development of economy in particular, and also the industrial development If the three pillars of the economy are defined as government, industry (supply side) and market (demand side), in developmental agencies would be the linkage among these three in order to facilitate the communication and operation. The study proved that Civil development companies and export development companies are having more potential for implementing the organization development rather that other two types of companies in Iran, furthermore the paranormal of organization development and expected services and results are important factors to improve therefore the Iranian governments should emphasis on directing political forces to development and decrease or omission of financial.

Corruptions among the group in favor and opposed inside the system. The study also discovered the vital elements of Facilitation \& Stabilization of Development as internal and external direction, direction of civil developmental companies, reinforce of organizational Development and organization development types in current scenario of Iranian government.

\section{A. Managerial Implications}

Today, almost all the Iranian organization development companies should rely heavily on company privatization as strategic tool to prevent further downturn in Iran. Strategically speaking the government should provide the platform and immense facility as main promotional factors and great influencer to shift companies towards organization development. The result of this study should consider as a great assess for all companies as framework for implementing the organization development with great strategically direction in each step. At present, research activities in the domain of Iranian organization development and privatization are very limited.

\section{B. Future Works}

One of the Iranian Mobile phone telecom network operators' necessities for gaining competitive advantage is to 
get feedback from subscribers as customers. This research will provide theses operators with appropriate opportunities to identify their strengths and weaknesses through statistical tests and figures as the feedback of clients' side for designing and planning the proper strategies which satisfy the customer's needs, wants and claims. The researchers intend to prepare the proposals for each operator and have discussion meetings with strategic managers of these operators in the near future.

\section{Research Limitations}

1. During the research, the researcher revealed that architecture of organization development is the key issue for sustainable Iranian economic therefore it is really difficult to expert in this field or if you find the expert, it is more difficult to get an appointment since they really have a tough schedule.

2. If you find the expert in this field by chance. It is really tough to obtain the secret governmental and political information and they prefer not to disclose the information with us.

3. The study is only based on a snowball sampling of only 15 experts in Tehran.

4. The inferences are based on the assumption that the data provided by respondent is true and correct.

\section{REFERENCES}

[1] Abdi, S. (2012). Identification of Existing Risks in a Variety of Projects Implementation Methods with an Emphasis on Using Public-Private Partnership The Collection of Public-Private Partnership Articles on the Development of Infrastructure / Development and Planning Consultant Centre (Research Institute of Management and Planning).

[2] Aker, D. (2013). Chain Referral Sampling. from https://explorable.com/snowball-sampling.

[3] Alpha, C. s. (2011). Wikipedia, the free encyclopedia. . from http://en.wikipedia.org/wiki/Cronbach's_alpha.

[4] Arthur M. Freedman, R. E. Z., Richard Freedman. (2002). Finding Your Way in the Consulting Jungle: A Guidebook for Organization Development Practitioners (Vol. 1). England: Wiley Book.

[5] Azizi, N. (2012). Conflict of Supporting Trade and Public Interests in the Field of Public Infrastructure in the Law System of Iran and the United Stated. The Collection of Public-Private Partnership Articles on the Development of Infrastructure / Development and Planning Consultant Centre (Research Institute of Management and Planning).

[6] Barzegar, M. (2012). The Participation of the Public sector and NGOs. The Collection of Public-Private Partnership Articles on the Development of Infrastructure / Development and Planning Consultant Centre (Research Institute of Management and Planning).

[7] Brenda B. Jones, M. B. (2006). The NTL Handbook of Organization Development and Change: Principles, Practices, and Perspectives (pp. 435). England Wiley.

[8] Cronbach's Alpha - Wikipedia, the free encyclopedia. Retrieved October 5, 2011, from http://en.wikipedia.org/wiki/Cronbach's_alpha.

[9] David L. Bradford, W. W. B. (2005). Reinventing Organization Development (Vol. 1). USA: Pfeiffer.

[10] Donald R. Brown, D. H. (2005). An Experiential Approach to Organization Development (Vol. 7). USA: Macgraw Hill.

[11] Fraenkel, J. R., \& Wallen, N. E. (2003). How to Design and Evaluate Research in Education USA: McGraw-Hill.

[12] Hair, J. F., Bush, R. P., \& Ortinau, D. J. (2003). Marketing Research Within a Changing Information Environment.

[13] Hair, J. F., Money, A. H., Samouel, P., \& Page, M. (2007). Research methods for business. England: John Wiley and Sons, Inc.

[14] J.-R. Desmurs, S. R. (2005). The Roots of Organic Development (Industrial Chemistry Library) (Vol. 2). England Wiley.

[15] Khalesi, M. (2012). Theoretical Principals and Global as well as Regional Experiences of Public-Private Partnership Arrangements for Development of Infrastructure. The Collection of Public-Private Partnership Articles on the Development of Infrastructure / Development and Planning Consultant Centre (Research Institute of Management and Planning).
[16] Kothari. (2008). Research Methodology: Methods and Techniques India: Age International Publishers.

[17] Ghanadiof, O. (2017). Customer loyalty and powerful brand in heavy machinery industry (Master dissertation, University of Tehran).

[18] Mosaee, M. (2012). The Study of Current Status of Regional and International Cooperation in Public-Private Partnership in Iran and Suggesting Ways to Foster it. The Collection of Public-Private Partnership Articles on the Development of Infrastructure / Development and Planning Consultant Centre (Research Institute of Management and Planning).

[19] Miremadi, A., \& Ghanadiof, O. (2021). CRM Competitive Strategy in Financial Institutions. European Journal of Business and Management Research, 6(3), 111-117.

[20] Ghanadiof, omidreza, \& Miremadi, A. (2018). Build your brand in one week.

[21] Ghanadiof, omidreza, Miremadi, A., \& Mohammadian, M. (2021). Strategic Planning and Strategic Analysis of Food Industry Using SWOT. Scientific Research Journals in Management and Social Studies, 2(23), 14-33.

[22] Fardhosseini, M. S., Soltaninejad, M., Karji, A., Ghorbani, Z., \& Ghanadiof, O. (2021). Qualitative Evaluation of 5S Application Considering the Experience of Electrical Construction Experts.

[23] Ghanadiof, O. (2021). Customer loyalty and powerful brand in heavy machinery industry. European Journal of Business and Management Research, 6(3). https://doi.org/10.24018/ejbmr.2021.6.3.903.

[24] Miremadi, A., Kenar Roudi, J., \& Ghanadiof, O. (2021). Evaluation on Role of Electronic Word of Mouth (EWOM) Ads in Customers' Emotions and Choices in E-Shops. International Journal of Industrial Marketing, 6(1). https://doi.org/10.5296/ijim.v6i1.

[25] Ghanadiof, O. (2021). Customer loyalty and powerful brand in heavy machinery industry. European Journal of Business and Management Research, 6(3). https://doi.org/10.24018/ejbmr.2021.6.3.903.

[26] Miremadi, A., \& Ghanadiof, O. (2021). The Ultimate Influences of Brand Equity Dimensions on Consumer Decision in Hi-Tech Market. Academic Journal of Research and Scientific Publishing. doi.org/10.52132/Ajrsp.e.2021.272.

[27] Ghanadiof, Omidreza, Sanayei, A., \& Emami, M. (2021). Effect Of Customer Perception On Seller Commitment In The Buyer-Seller Relationship. European Journal of Business and Management.

[28] Cummings, T. G., \& Worley, C. G. (1993). Organization Development and Change, St Paul. 